\title{
Relationship between grain size distribution and intertidal faunal abundance in selected stations of Someshwara, Panambur and Bengre beaches
}

\author{
Daggula Narshivudu雨, Lakshmipathi M.T., Padmanaba A., Vadithe Reddynaik, Kummari \\ Suresh, Bhukya Bhaskar, Lingesh
}

Received: 29.06.2018

Revised: 28.08.2018

Accepted: 14.09.2018

\begin{abstract}
The knowledge of sediment texture is important in the studies of distribution of living and non-living resources, identification of source of sediments, sediment patterns and nutrients. It is known that the macro-benthos in the aquatic environment are influenced by the texture of the sediment in which they establish themselves and live. Sediment quality guidelines are important tool for assessment of contamination in marine and estuarine sediments with biological significance of intertidal beaches. The grain size characteristics of sediments from aggrading and receding in beaches have been analyzed by several investigators, only very limited research has been done on the relationship between the intertidal faunal abundance, distribution and the sediment grain size distributions from eroding and accreting beaches of Mangaluru. Sediment variations mainly affect the species distribution, pattern of diversity, breeding, survival and other activities. The present study was carried out to determine the grain size distribution and species abundance in coastal Waters of Someshwara, Panambur and Bengre beaches along the Mangaluru, south west coast of India. The sampling of coastal water and sediment was carried out from August 2016 to July 2017 along the Mangaluru coast was studied. Spatial and temporal variations of the grain size distribution like granules, coarse sand, fine sand, and very fine sand textural components like sand, silt, clay and organic carbon percentages analyzed and correlated with intertidal species distribution, abundance in the selected stations.
\end{abstract}

Key words: Intertidal species, grain size distribution, sediment texture, Coastal beaches, Mangaluru.

\section{Introduction}

The Someshwara beach is parallel to Netravathi River, which greatly receives fresh water inflow from the river, land nutrients, municipality, and domestic sewage, decayed plant and animal matter, pesticides from agriculture activities. Panambur beach is a part of Mangaluru port area located at one end which handles high sea traffic. And another end fertilizer and oil industries and domestic sewage from coastal side fisher folk this area is highly industrialized and also one of the famous touristic spot in Mangaluru. The Bengre is a small island in Mangalore city with few of the Mangalorean population staying there located near to old Mangalore port. This beach affects mainly inflow of wastewaterand domestic sewage from fish meal plants and small industries. Dredging activities are also going on this area.

Author's Address

Krishi Vigyan Kendra, Kampasagar

E-mail.: narshiva007@gmail.com

Copyright by ASEA

All rights of reproduction in any form reserved

\section{Materials and Methods}

The study have been carried out for a period of one year from August 2016 to July 2017 along the selected beaches (Someshwara, Bengre and Panambur) of Mangalore, Karnataka (Fig.1). A total of nine stations designated as S1, S2, S3, P1, P2, P3, B1, B2 and B3 (Fig.1). The sediment samples were collected by using scoop and placed in plastic cover for further analysis in the laboratory.

\section{Sediment collection}

A hand corer $\left(0.1 \mathrm{~m}^{2}\right.$ diameter size, depth $\left.10 \mathrm{~cm}\right)$ was used to collect the sediment from the study area. The organic carbon content of the sediment was determined by the method given by El-wakeel and Riley (1957). The results were expressed in percentage of organic carbon in dry sediment. Clean well dried samples were first made free from molluscan shells, large stones, and dried grasses. 
About $100 \mathrm{~g}$ of dried sediment sample was weighed accurately and transferred to a $250 \mathrm{ml}$ capacity beaker. The sample was made salt free by washing repeatedly with distilled water. Approximately 50 $\mathrm{ml}$ of $10 \%$ sodium hexametaphosphate solution was added to the sediment and soaked overnight. Subsequently, the sample was sieved through a 62 $\mu \mathrm{m}$ size seiver. The sand fraction retained on the
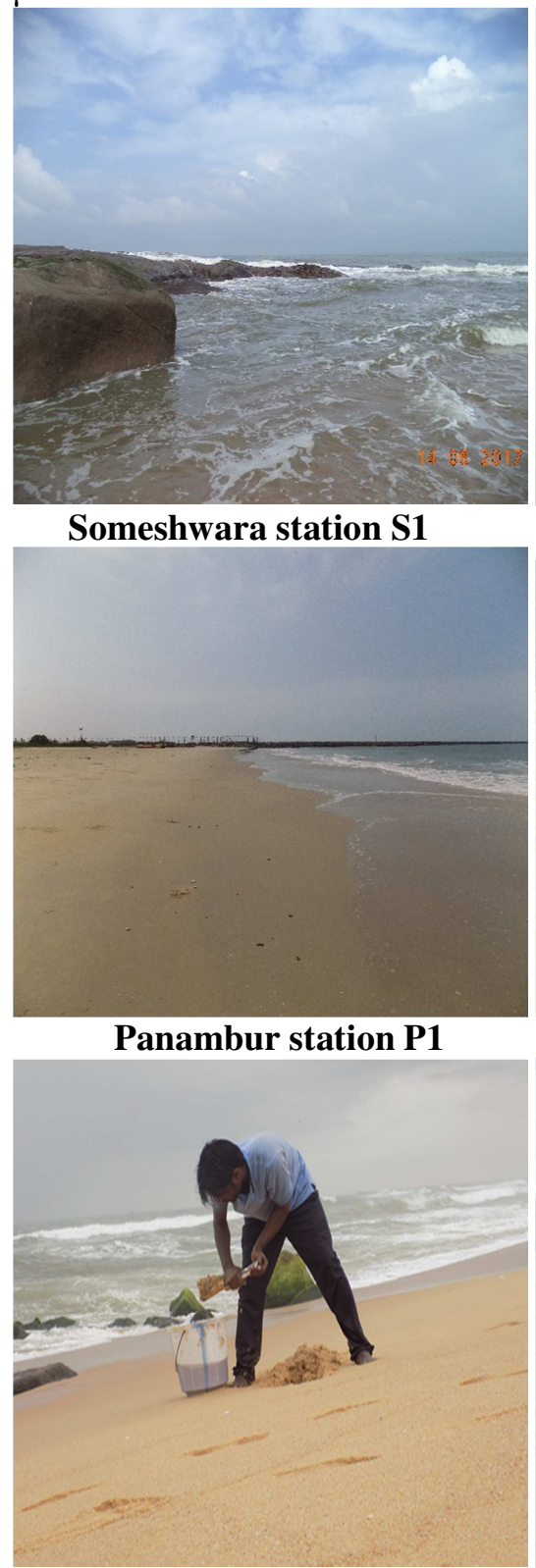

Bengre station B1

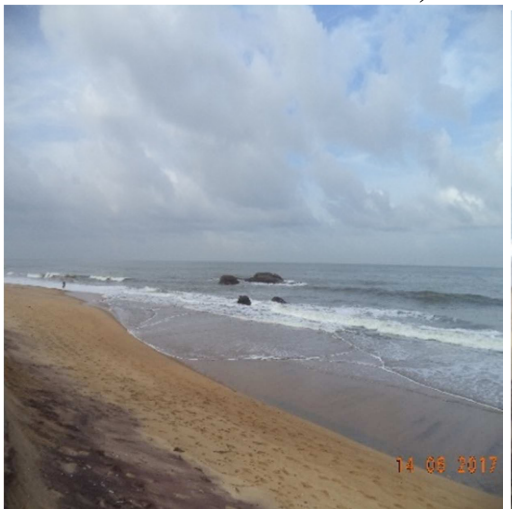

Someshwara station S2

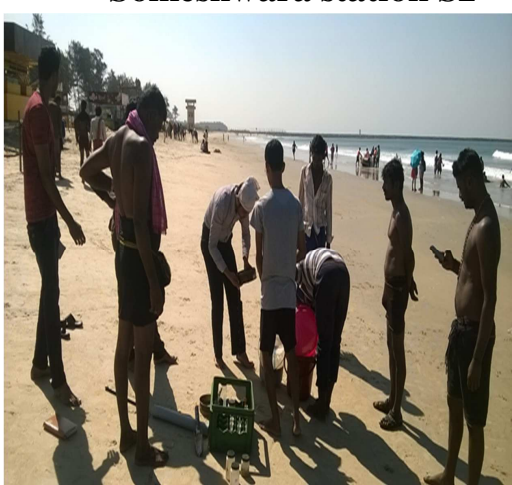

Panambur station P2

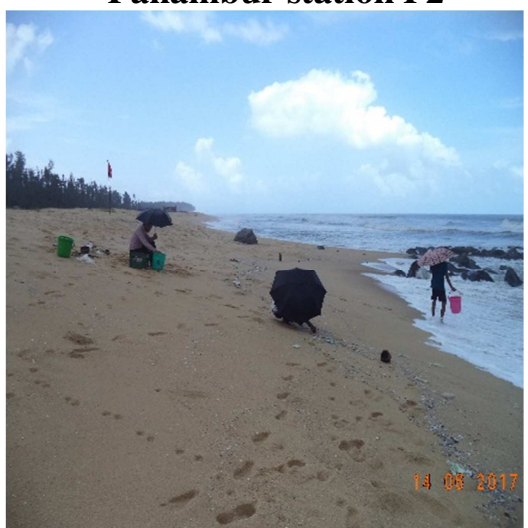

Bengre station B2 sieve was dried and weighed. The sediment fraction was collected in a $1000 \mathrm{ml}$ beaker and transformed to a $1000 \mathrm{ml}$ measuring glass cylinder and subjected to pipette analysis (Buchanan and Kain, 1971). The dried sand was sieved for size fractions analysis with the help of sieve shaker by following ASTM number (American Standards for Testing Materials).

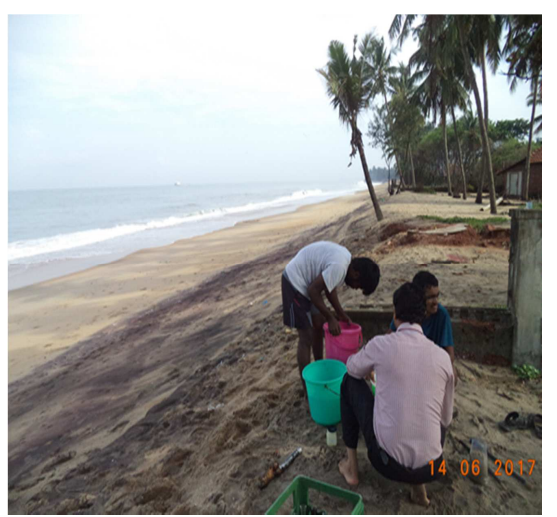

Someshwara station S3

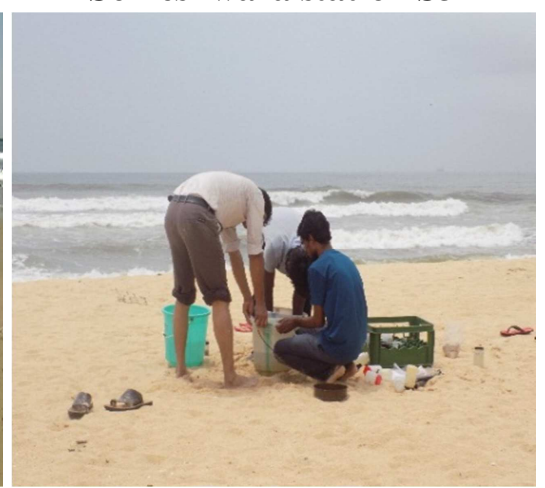

Panambur station P3

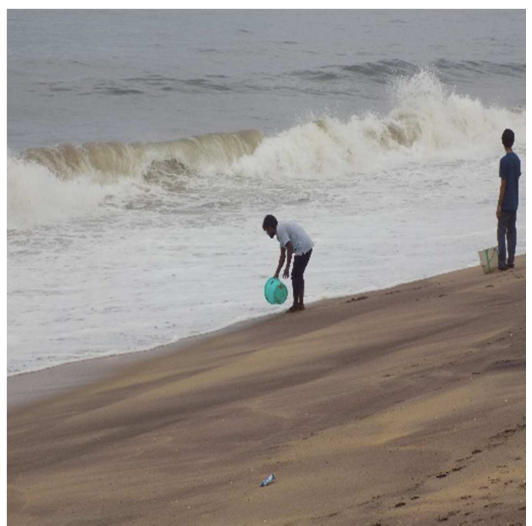

Bengre station B3

Figure1. Geographical position of stations selected for the study 


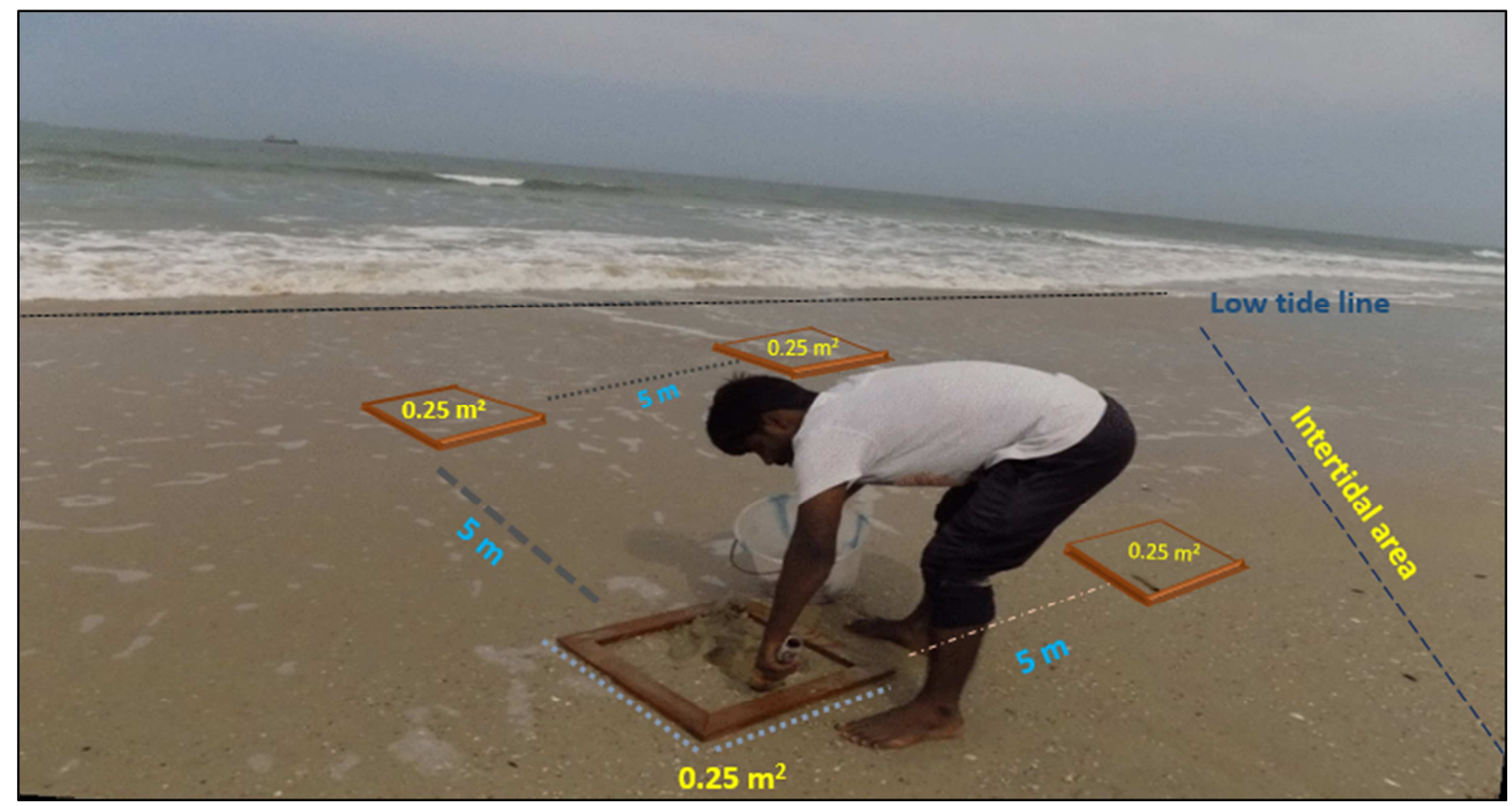

Figure 2. Qualitative and Quantitative composition of Intertidal fauna
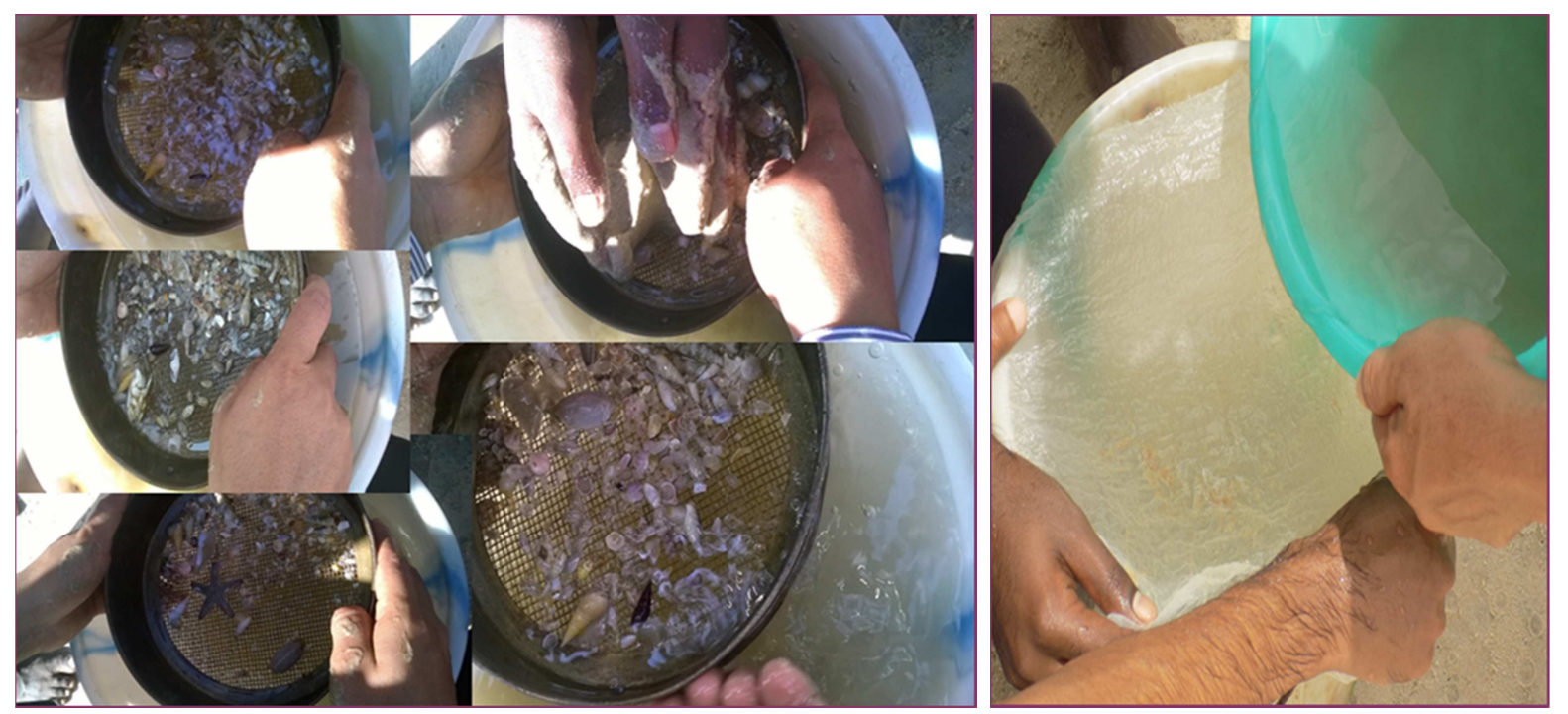

Figure 3.Collection of intertidal organisms and planktonic larvae

In the laboratory, intertidal organisms were sorted out and identified up to generic/species level. The numerical abundance of intertidal organisms expressed in terms of No. $/ \mathrm{m}^{2}$. The simple correlation was determined between various physico-chemical parameters such as water temperature, $\mathrm{pH}$, salinity, dissolved oxygen, nutrients and sediment fractions.

\section{Results and Discussion}

Growth, production, survival and reproduction of aquatic organisms are influenced by physical, chemical and biological characteristics of water. The percentage occurrence and distribution of different size components of sediment (granules, very coarse sand, coarse sand, medium sand, fine sand, very fine sand, silt and clay) of selected 


\section{Daggula et al.}

beaches of Mangaluru are depicted graphically in below figures. The different size fractions of sand contributing to the sediment components according to American Standards for Testing Materials (ASTM), granules size above the $(2.0 \mathrm{~mm})$, very coarse sand size from (2.00 to $1.18 \mathrm{~mm})$, coarse sand size from (1.18 to $425 \mu \mathrm{m})$, medium sand size from $(425$ to $212 \mu \mathrm{m})$, fine sand size from (212 to $106 \mu \mathrm{m})$, very fine sand size from (106 to $63 \mu \mathrm{m})$ and silt and clay below the $(63 \mu \mathrm{m})$. A perusal of the data presented reveals that the fractions show considerable seasonal variations in occurrence and abundance. Generally fractions of granules, slit and clay contributed to lesser degree to the total of sediment to great extent coarse sand, medium sand, fine sand showed dominant tendency in the selected beach of Mangaluru. Tropical intertidal areas are highly dynamic owing to variation in the tidal forces and energy of waves at the confluence result in a complicated sedimentary environment. Hopkison et al. (1999) contented that sediments play an important role in organic matter degradation and nutrient recycling in aquatic ecosystems.

\section{Someshwara beach}

Abundance of sediment fractions were in the order of coarse sand $(51.21 \%)>$ medium sand $(27.64 \%)$ $>$ very coarse sand $(9.98 \%)>$ fine sand $(5.61 \%)>$ very fine sand $(0.53 \%)>$ granules $(3.50 \%)>$ silt and clay $(1.50 \%)$.
Station S1 (Fig 4): Someshwara beach at station (S1) high percentage of coarse sand was recorded. The percentage of coarse sand varied from $45.33 \%$ in September (monsoon) to $80.31 \%$ April (premonsoon), medium sand varied from $3.88 \%$ in April (pre-monsoon) to $32.48 \%$ in July (monsoon), very coarse sand \% varied from $1.21 \%$ December (post-monsoon) to $22.61 \%$ in June (monsoon), fine sand varied from $0.29 \%$ in December (postmonsoon) to $6.28 \%$ November (post-monsoon), very fine sand varied from $0.0 \%$ June, July (monsoon) to $1.30 \%$ November (post-monsoon), silt and clay varied from $0.40 \%$ in January (postmonsoon) to $2.50 \%$ in July (monsoon).

Station S2 (Fig 5): Someshwara beach at station (S2) coarse sand and medium sand percentages were high. The percentage of coarse sand varied from $32.73 \%$ in June (monsoon) to $60.05 \%$ July (monsoon), medium sand varied from $16.87 \%$ in September (monsoon) to $47.02 \%$ in June (monsoon), very coarse sand varied from $2.68 \%$ in December (post-monsoon) to $27.36 \%$ in September (monsoon), fine sand varied from $2.88 \%$ in October (post-monsoon) to $8.26 \%$ May (pre-monsoon), very fine sand varied from $0.00 \%$ July (monsoon) to $1.34 \%$ January (post-monsoon), silt and clay varied from $0.50 \%$ in January (post-monsoon) to $2.70 \%$ in July (monsoon).

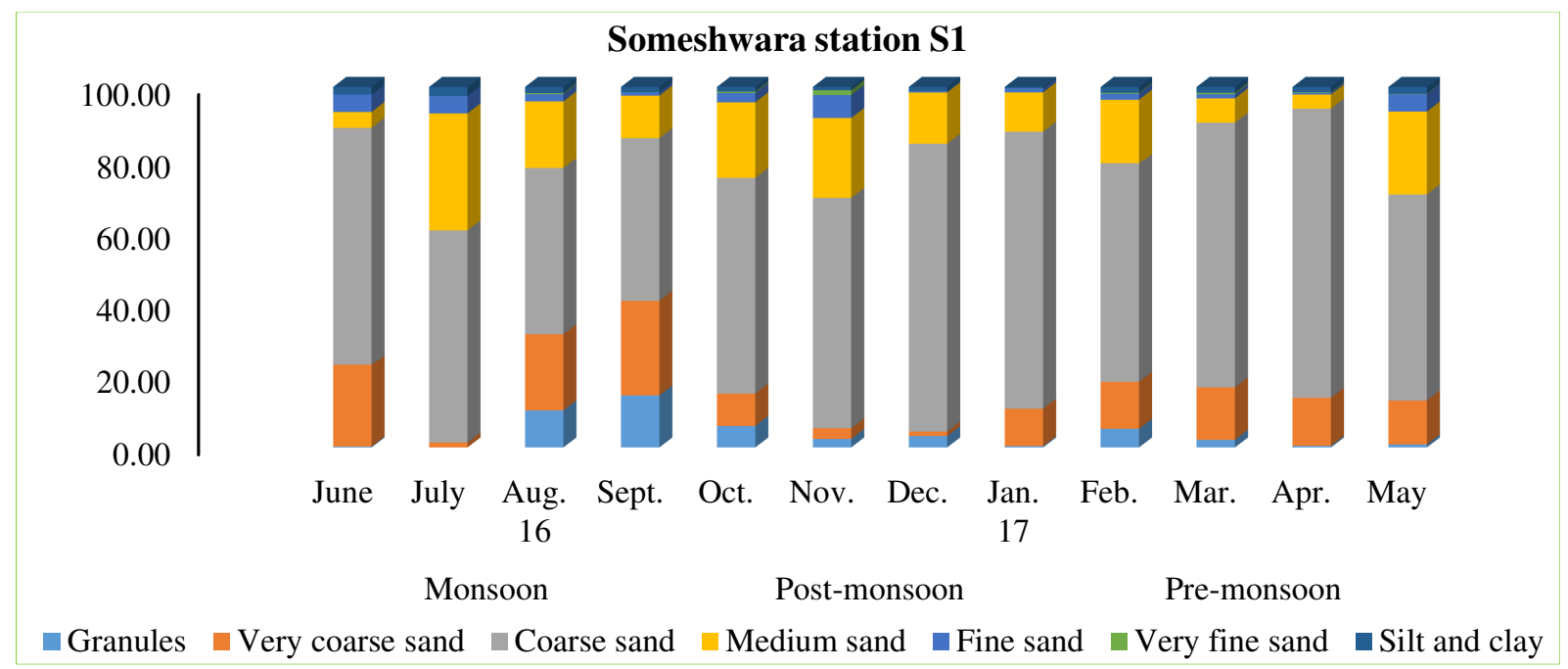

Figure 4. Percentage occurrence and distribution of different size components of sediment (granules, very coarse sand, coarse sand, medium sand, fine sand, very fine sand, silt and clay) of Someshwara station Site-1. 


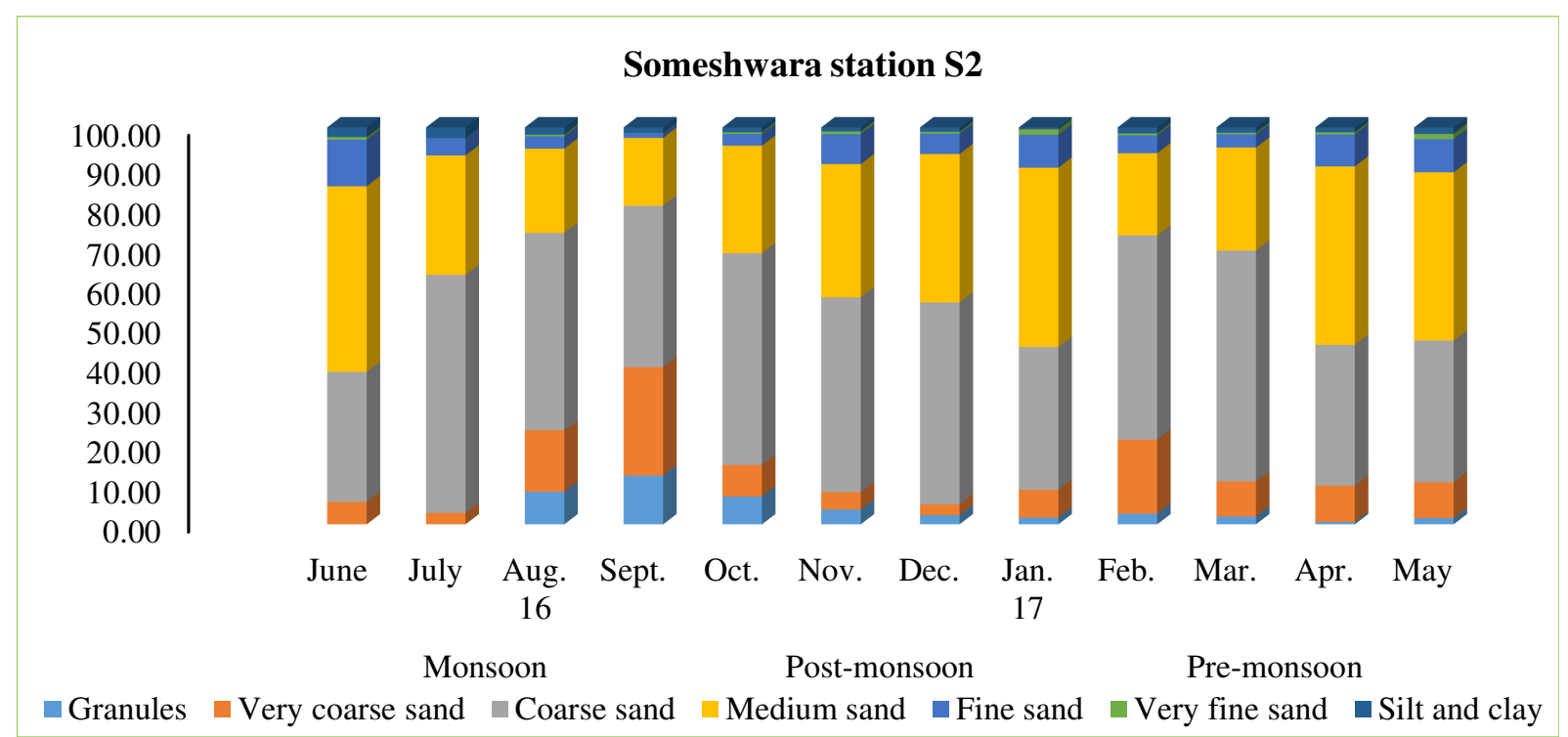

Figure 5. Percentage occurrence and distribution of different size components of sediment (granules, very coarse sand, coarse sand, medium sand, fine sand, very fine sand, silt and clay) of Someshwara station Site-2.

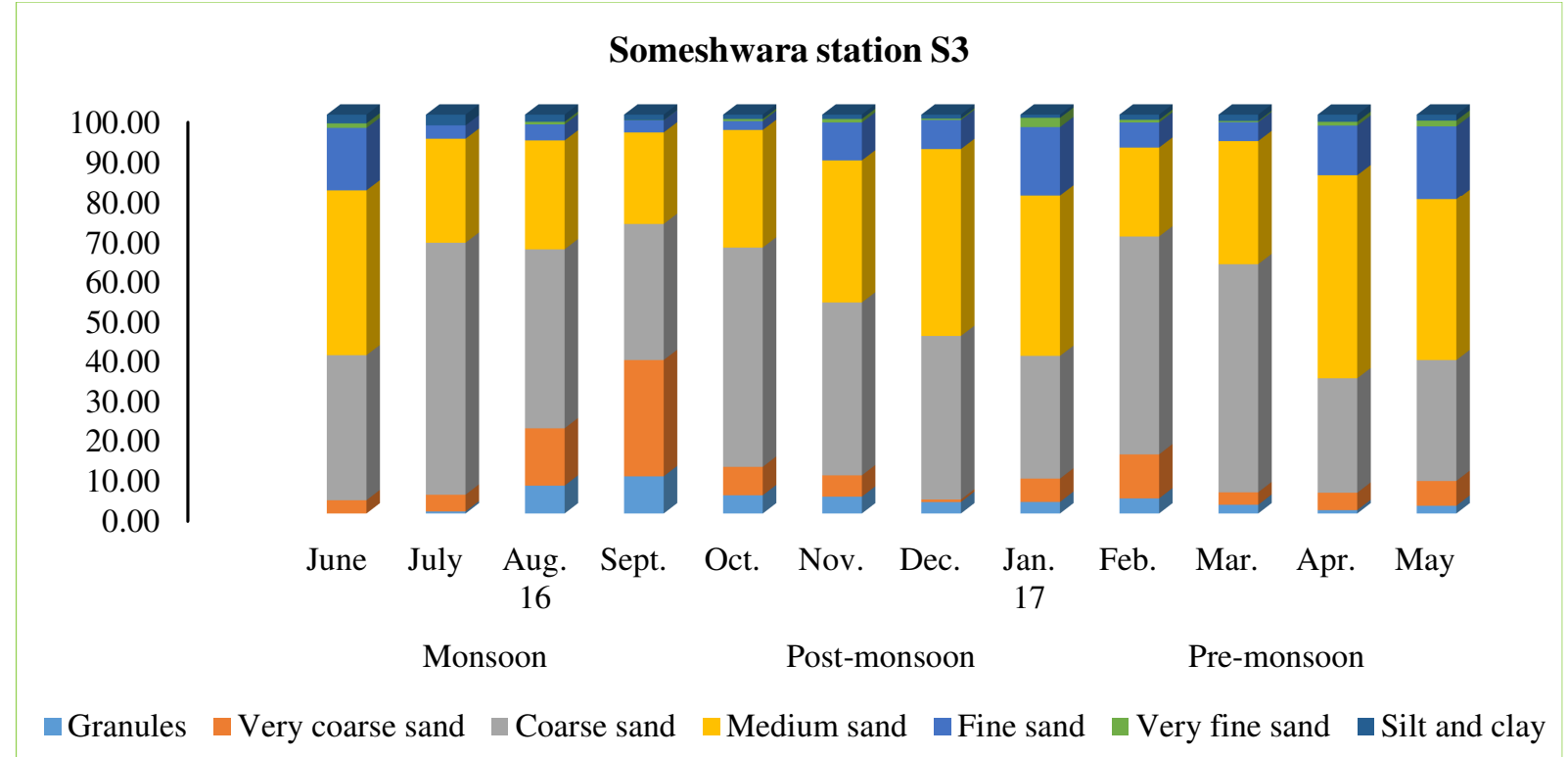

Figure 6. Percentage occurrence and distribution of different size components of sediment (granules, very coarse sand, coarse sand, medium sand, fine sand, very fine sand, silt and clay) of Someshwara station Site-3.

Station S3 (Fig 6): Someshwara beach at station in April (pre-monsoon) to 55.08\% in October (S3) medium sand and coarse sand percentages (post-monsoon), fine sand varied from 2.22\% in were high. The percentage of medium sand varied October (post-monsoon) to 18.45\% May (prefrom $22.42 \%$ in February (pre-monsoon) to $51.08 \%$ monsoon), very fine sand varied from $0.00 \%$ July in April (pre-monsoon), coarse sand varied from (monsoon) to 2.32\% January (post-monsoon), silt $28.62 \%$ in April (pre-monsoon) to $63.14 \%$ July and clay varied from $0.80 \%$ in January (post(monsoon), very coarse sand varied from $28.62 \%$ monsoon) to $2.70 \%$ in July (monsoon). 
Panambur beach

Abundance of sediment fractions were in the order of fine sand $(49.35 \%)>$ medium sand $(31.09 \%)>$ coarse sand $(9.10 \%)>$ very fine sand $(7.97 \%)>$ very coarse sand $(0.474 \%)>$ silt and clay $(1.98 \%)$ $>$ granules $(0.003 \%)$.

Station P1 (Fig 7): Panambur beach at station (P1) high percentages of fine sand, medium sand and very fine sand were recorded. The percentage of fine sand varied from $25.70 \%$ in July (monsoon) to $66.58 \%$ in May (pre-monsoon), medium sand varied from $15.12 \%$ in April (pre-monsoon) to $53.54 \%$ July (monsoon), coarse sand \% varied from $0.99 \%$ in May (pre-monsoon) to $25.04 \%$ in August (monsoon), very fine sand varied from $0.14 \%$ in June (monsoon) to $23.20 \%$ in February (premonsoon), very coarse sand varied from $0.07 \%$ in July (monsoon) to $0.89 \%$ in February (premonsoon), silt and clay varied from $0.80 \%$ in April (pre-monsoon) to $3.30 \%$ in July

(monsoon) and granules percentage was not observed in the study period.

Station P2 (Fig 8): Distribution of sediment fractions in Panambur beach (P2) are graphically depicted in Fig 8 in Panambur beach at station (P2) fine sand and medium sand percentage were high. The percentage of fine sand varied from $38.18 \%$ in
July (monsoon) to $64.23 \%$ in April (pre-monsoon), medium sand varied from $19.11 \%$ in April (premonsoon) to $42.26 \%$ July (monsoon), coarse sand varied from $3.54 \%$ in April (pre-monsoon) to $18.13 \%$ in October (post-monsoon), very fine sand varied from $0.01 \%$ in August (monsoon) to $18.64 \%$ in February (pre-monsoon), very coarse sand varied from $0.10 \%$ in July (monsoon) to $1.09 \%$ in June (monsoon), silt and clay varied from $1.20 \%$ in November (post-monsoon) to $3.00 \%$ in July (monsoon) and granules percentage was not observed in the study period.

Station P3 (Fig 9): Panambur beach at station (P3) fine sand and medium sand percentages were high. The percentage of fine sand varied from $40.28 \%$ in July (monsoon) to $67.77 \%$ in April (pre-monsoon), medium sand varied from $10.96 \%$ in January (postmonsoon) to $40.57 \%$ in August (monsoon), coarse sand varied from $2.36 \%$ in April (pre-monsoon) to $14.11 \%$ in October (post-monsoon), very fine sand varied from $0.04 \%$ in August (monsoon) to $30.60 \%$ in January (post-monsoon), very coarse sand varied from $0.03 \%$ in September (monsoon) to $2.62 \%$ in October (post-monsoon), silt and clay varied from $1.30 \%$ in January and February (post and premonsoon) to $3.50 \%$ in July (monsoon) and granules percentage $0.04 \%$ in (October)observed in the study period.

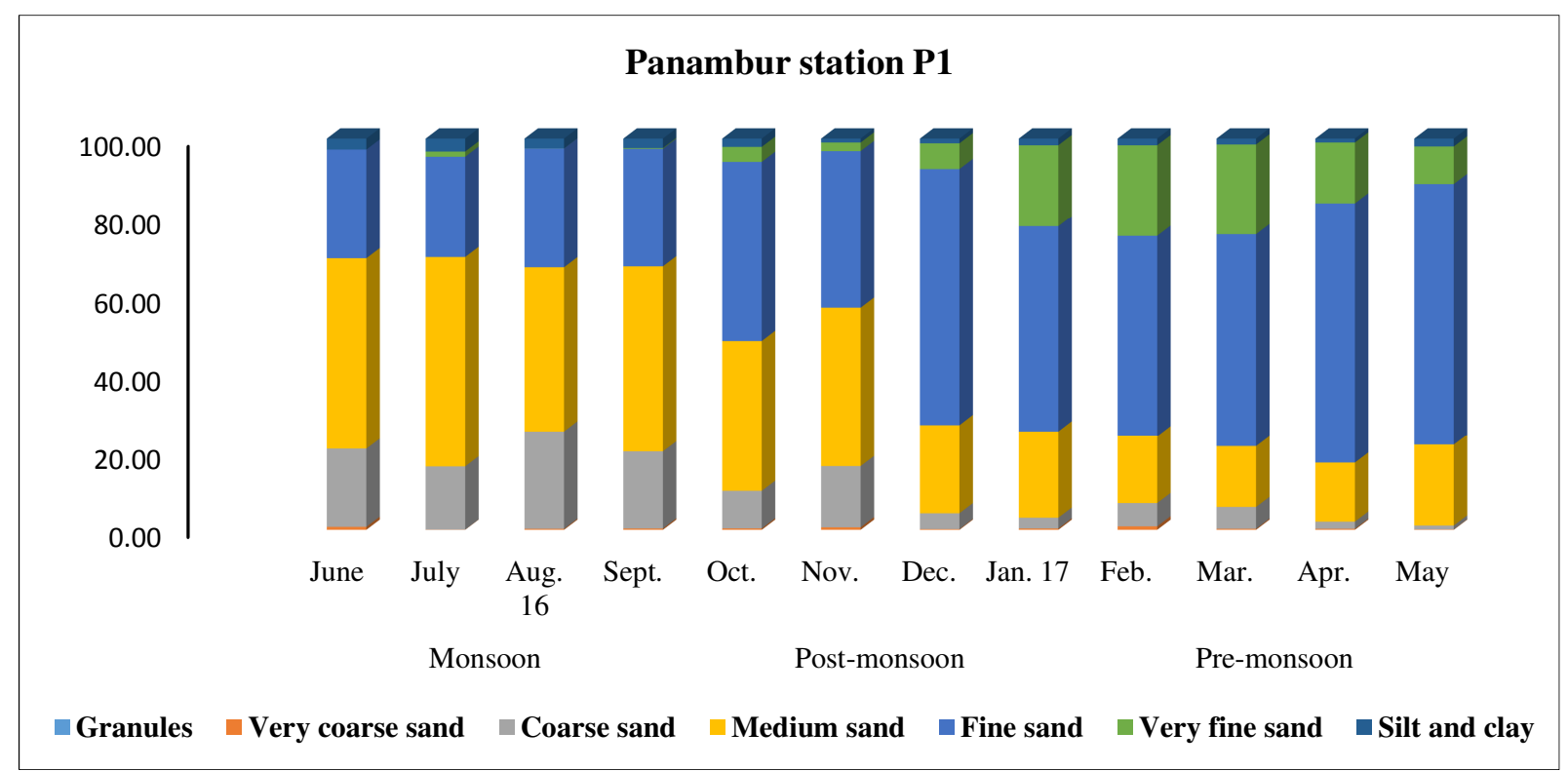

Figure 7. Percentage occurrence and distribution of different size components of sediment (granules, very coarse sand, coarse sand, medium sand, fine sand, very fine sand, silt and clay) of Panambur beach Site-1. 
Relationship between grain size distribution and intertidal faunal abundance

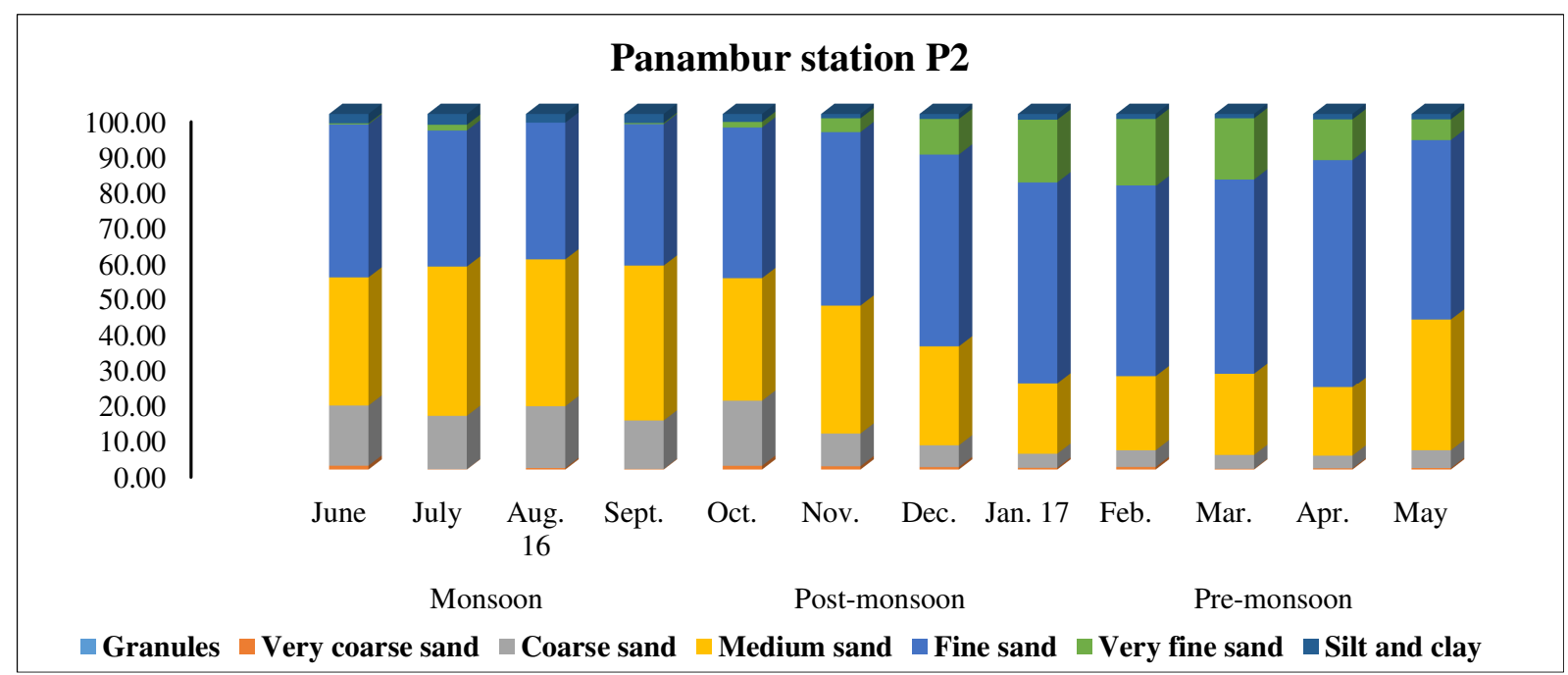

Figure 8. Percentage occurrence and distribution of different size components of sediment (granules, very coarse sand, coarse sand, medium sand, fine sand, very fine sand, silt and clay) of Panambur beach Site-2.

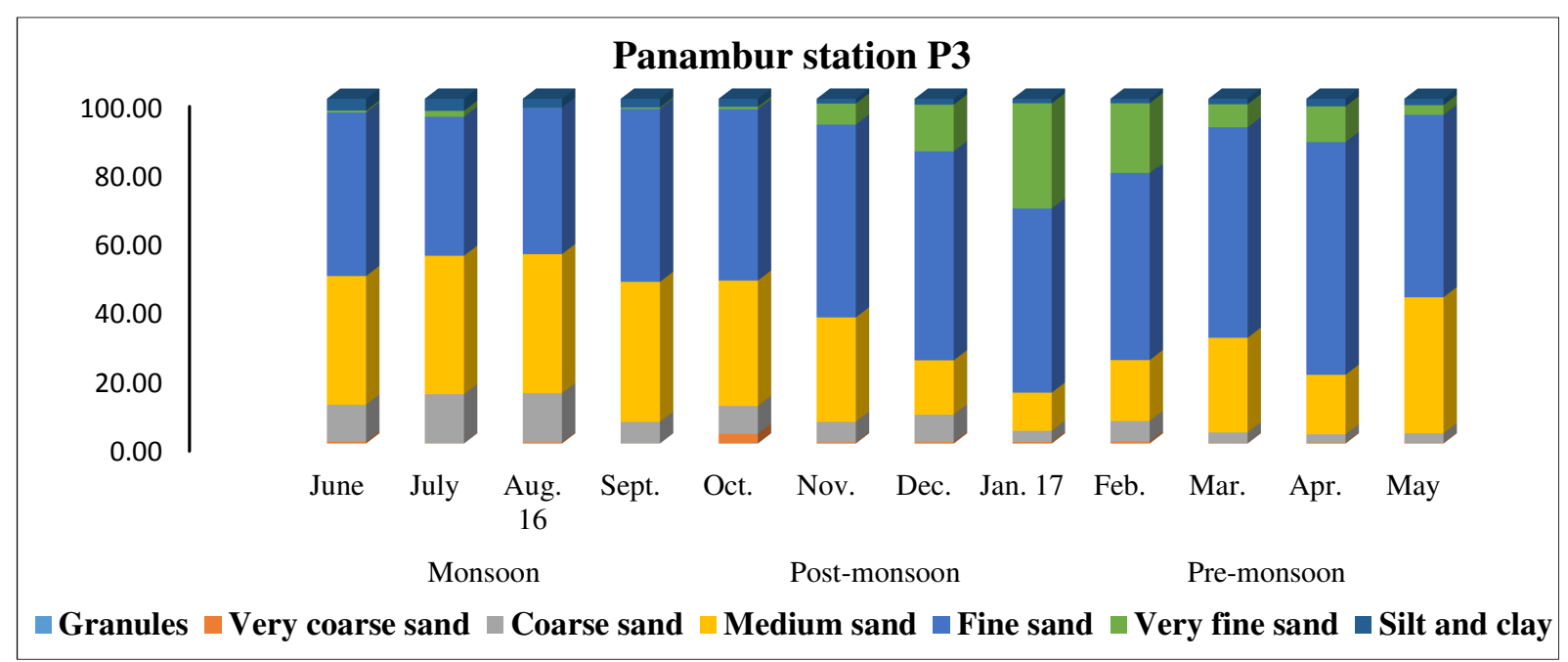

Figure 9. Percentage occurrence and distribution of different size components of sediment (granules, very coarse sand, coarse sand, medium sand, fine sand, very fine sand, silt and clay) of Panambur beach Site-3.

\section{Bengre beach}

Station B1 (Fig 10): Bengre beach at station (B1), high percentages of medium sand, coarse sand and fine sand were recorded. The percentage of coarse sand varied from $1.42 \%$ in April (pre-monsoon) to $42.79 \%$ in July (monsoon), fine sand varied from $4.88 \%$ in July (monsoon) to $75.84 \%$ in October (post-monsoon), medium sand varied from $10.40 \%$ in April (pre-monsoon) to $48.23 \%$ in July (monsoon), very fine sand varied from $0.00 \%$ in July (monsoon) to $23.44 \%$ in January (postmonsoon), very coarse sand varied from $0.13 \%$ in April (pre-monsoon) to $3.33 \%$ in August

(monsoon), silt and clay varied from $0.60 \%$ in October (post-monsoon) to $2.60 \%$ in July (monsoon) and granules percentage was $(0.70 \%$ in post-monsoon) observed in the study period.

Station B2 (Fig 11): Bengre beach at station (B2) coarse sand, medium sand and fine sand percentages were high. The percentage of coarse sand varied from $30.36 \%$ in April (pre-monsoon) to $51.71 \%$ in July (monsoon), fine sand varied from $4.03 \%$ in July (monsoon) to $22.08 \%$ in June (monsoon), medium sand varied from $28.45 \%$ in September (monsoon) to $43.80 \%$ in November 


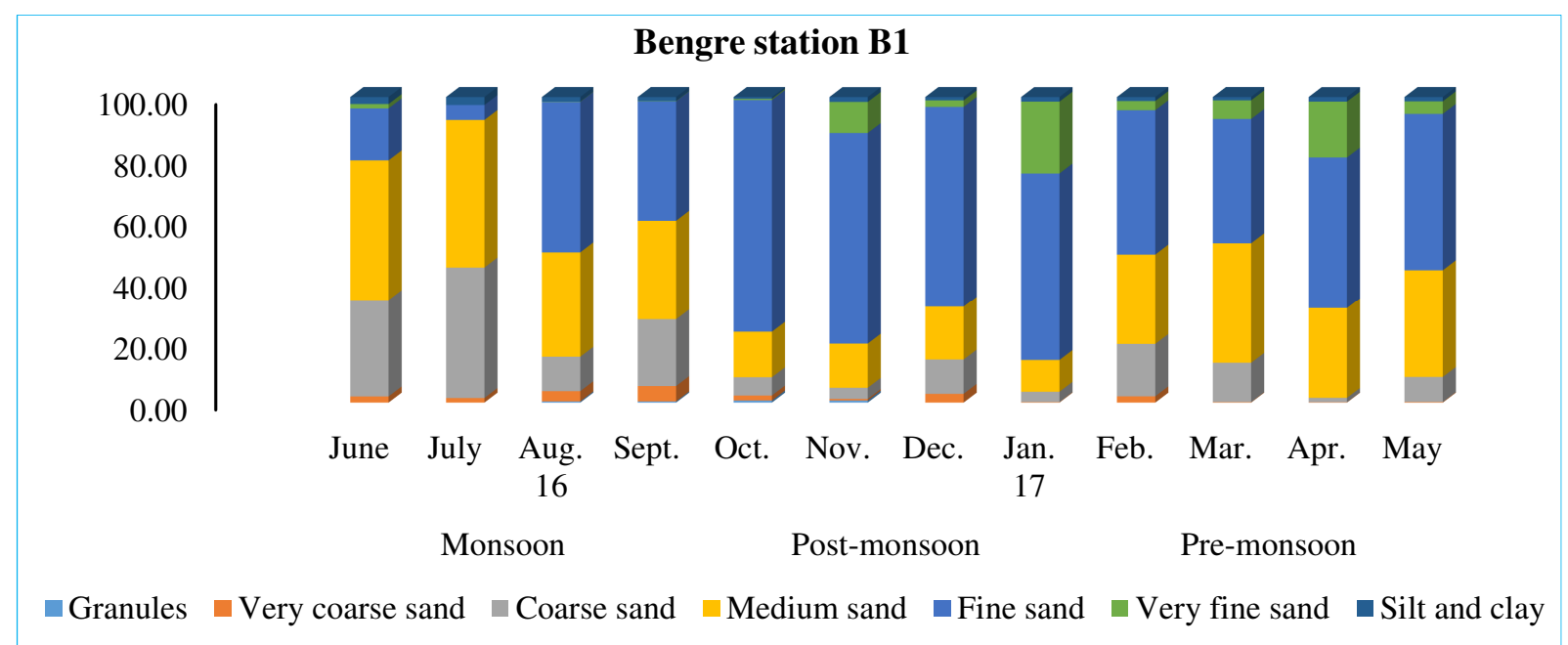

Figure 9. Percentage occurrence and distribution of different size components of sediment (granules, very coarse sand, coarse sand, medium sand, fine sand, very fine sand, silt and clay) of Bengre beach Site-1.

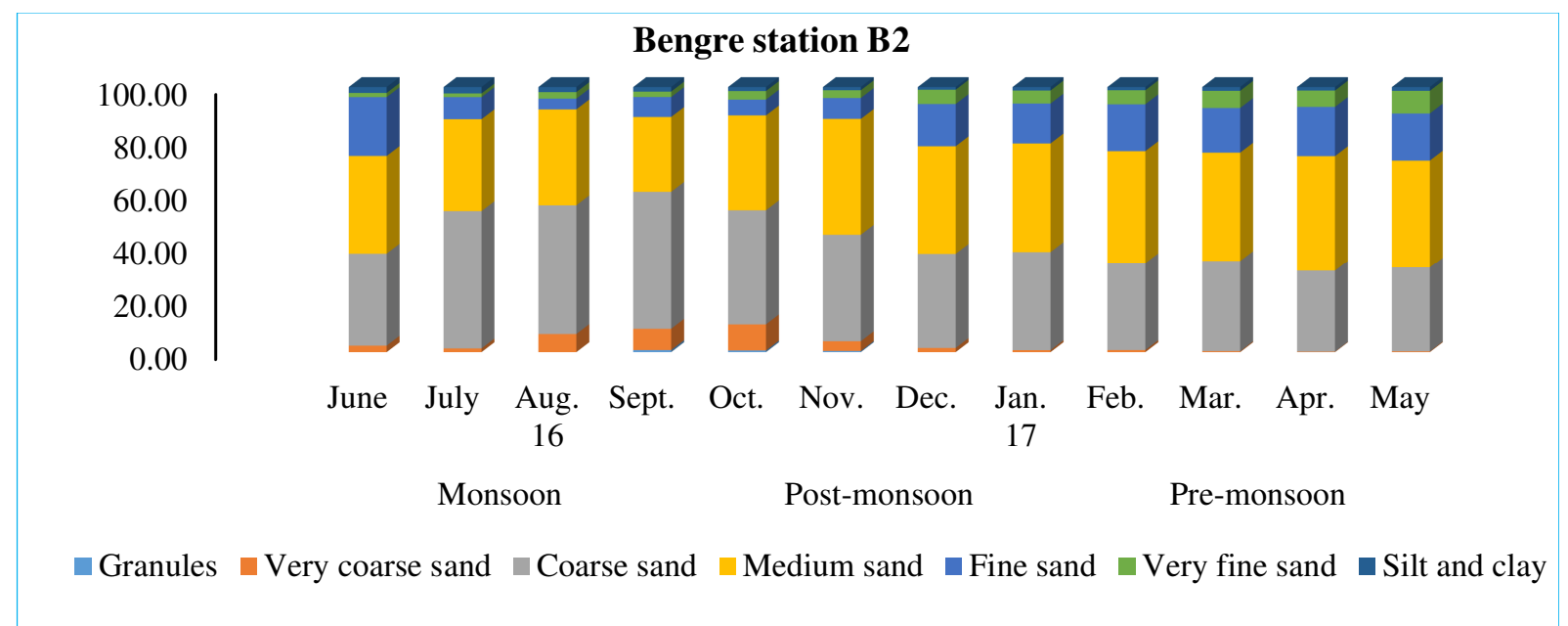

Figure 10. Percentage occurrence and distribution of different size components of sediment (granules, very coarse sand, coarse sand, medium sand, fine sand, very fine sand, silt and clay) of Bengre beach Site-2.

(post-monsoon), very fine sand varied from 1.38\% June (monsoon), fine sand varied from $4.42 \%$ in in July (monsoon) to $8.50 \%$ in May (pre-monsoon), July (monsoon) to $21.06 \%$ in April (pre-monsoon), very coarse sand varied from $0.19 \%$ in April (pre- medium sand varied from $39.43 \%$ in July monsoon) to $9.76 \%$ in October (post-monsoon), silt (monsoon) to $50.06 \%$ in April (pre-monsoon), very and clay varied from $1.00 \%$ in December (post- fine sand varied from $1.64 \%$ in August (monsoon) monsoon) to $2.40 \%$ in July (monsoon) and granules to $8.40 \%$ in February (pre-monsoon), very coarse percentage was $0.63 \%$ in (post-monsoon) observed sand varied from $0.00 \%$ in April (pre-monsoon) to in the study period.

6.54 in October (post-monsoon), silt and clay

Station B3 (Fig 12): Bengre beach at station B3, varied from 1.10\% in December and January (postmedium sand and coarse sand percentages were monsoon) to $2.30 \%$ in July (monsoon) and granules high (Fig 12). The percentage of coarse sand varied percentage was ( $0.56 \%$ in August) not significantly from $24.05 \%$ in April (pre-monsoon) to $45.28 \%$ observed in the study period. 


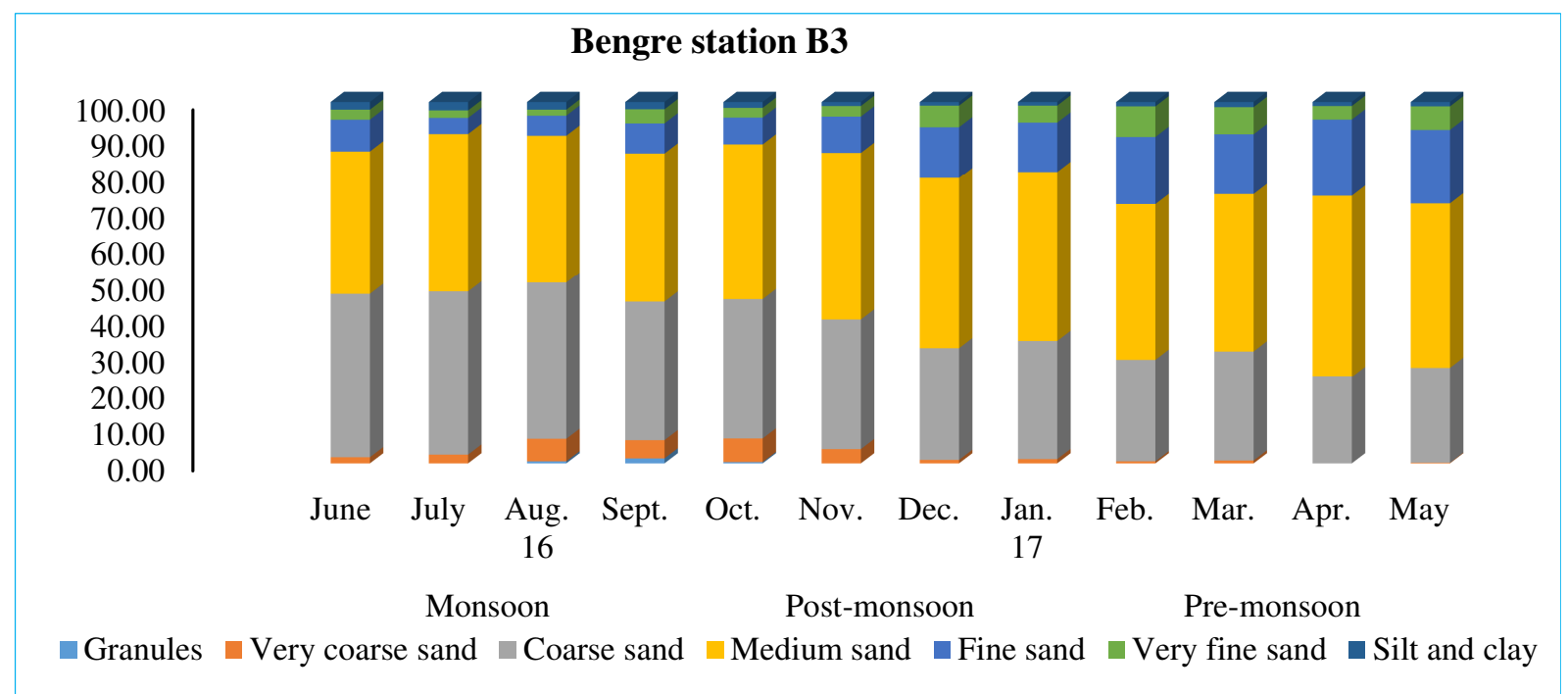

Figure 10. Percentage occurrence and distribution of different size components of sediment (granules, very coarse sand, coarse sand, medium sand, fine sand, very fine sand, silt and clay) of Bengre beach Site-3.

Over all study period the majority of sediment fractions percentage occupied by coarse sand in Someshwara, fine sand abounded in Panambur beach, equally medium and coarse sand distributed in Bengre beach and the negligible percentage of granules, silt and clay in all the selected beaches of Mangaluru. In general the Karnataka coastline has about $75 \%$ sandy beach, $11 \%$ rocky coast, and $14 \%$ mud flats, in sandy beaches three main factors that control the sediment grain size distribution: they are the sediment source, wave energy level and the general offshore slope on which the beach is constructed in coastal beaches (Komar, 1976 and Engstrom 1974). From the collected data, it was found that the sand fraction ranged from 97.88 to $99.54 \%$ further sand fractions were analyzed high percentage of coarse sand fraction $(51 \%)$ was observed at Someshwara beach compared to Panambur beach and Bengre beach. The fine sand concentration $(49 \%)$ was observed at Panambur beach. Bengre beach medium sand (37\%), coarse sand $(30 \%)$ and fine sand $(24 \%)$ were observed. granules, clay and silt concentration not in significant range at all the selected beaches. The data obtained on sediments at study sites revealed a clear cut dominance of sand over silt and clay. The sand fraction ranged from 97.88 to $99.54 \%$. The high percentage of coarse sand fraction $(51 \%)$ was observed at Someshwara beach compared to Panambur beach and Bengre beach. The fine sand concentration (49\%) was observed at Panambur beach. Bengre beach medium sand (37\%), coarse sand $(30 \%)$ fine sand $(24 \%)$ were observed. granules, clay and silt concentration not in significant range. The grain size distribution of sediment is mostly between medium to fine sand over the Mangaluru coast beaches Komar (1998). Reddy Gopala (1982) reported the dominance of sand, followed by silt and clay in NethravatiGurupur estuary. Ramachandra et al. (1984) documented the dominance of sand and equal contribution of silt and clay in the sediments of Mulki estuary. Seralathan et al. (1993) in the Cochin harbor observed higher percentage of sand and equal contribution of silt and clay. Chakraborty (2011) reported that considerable and continuous erosion processes have led to make the water bodies turbid and to promote unwanted accretion.

The grain size distribution ranged from 0.18 to 2.22 depicting it as very coarse to fine. However, in most of the observations the sand was found to be medium to coarse in nature. This characteristic of the intertidal sediment can be attributed to the higher wave energy regime due to local topography that prevents sedimentation of fine-grained particles. Reports by Selvaraj and Ram Mohan (2003) and Srinivasalu et al. (2007) from the same locality confirmed that the sediments are mainly of fine to medium grained sand similarly sediment texture analyses were done by Manjappa (1999) 
Daggula et al.

and Prashanth (2010). Amrutha (2010) were studied $32.9 \%$ of silt and 2.1 to $58.3 \%$ of clay in the in Netravathi-Gurupura estuary. Bagadeeshwaran et Arasalar estuary, Karikal, south east coast of India. al. (2007) observed 21.3 to $90.3 \%$ of sand 4.5 to

Table1. Qualitative distribution of intertidal fauna at selected stations during August 2016 to July 2017

\begin{tabular}{|c|c|c|c|c|c|c|c|c|c|}
\hline \multirow{2}{*}{ Intertidal fauna } & \multicolumn{3}{|c|}{ Someshwara } & \multicolumn{3}{|c|}{ Panambur } & \multicolumn{3}{|c|}{ Bengre } \\
\hline & S1 & $\mathbf{S 2}$ & S3 & P1 & $\mathbf{P 2}$ & $\mathbf{P 3}$ & B1 & B2 & B3 \\
\hline \multicolumn{10}{|l|}{ MOLLUSCS } \\
\hline \multicolumn{10}{|l|}{ Bivalves } \\
\hline Arca spp. & + & + & + & + & + & + & + & + & + \\
\hline Anadaragranosa & + & + & + & + & + & + & + & + & + \\
\hline Bivalve spats & + & + & + & + & + & + & + & + & + \\
\hline Cardium spp. & + & + & + & + & + & + & + & + & + \\
\hline Crassostrea spp. & + & + & - & + & - & - & + & + & + \\
\hline Donaxfaba & - & + & + & + & + & + & + & + & + \\
\hline Donaxscortum & + & + & + & + & + & + & + & + & + \\
\hline Dosinia spp. & + & + & + & + & + & + & + & + & + \\
\hline Meritrixcasta & + & + & + & + & + & + & + & + & + \\
\hline Meritrix spp. & + & + & + & + & + & + & + & + & + \\
\hline Paphia spp. & + & - & + & + & + & + & + & + & + \\
\hline Paphiamalabarica & + & + & - & + & + & + & + & - & - \\
\hline Pecten spp. & - & - & - & + & + & + & + & + & + \\
\hline Pernaviridis & + & + & + & + & + & + & + & + & + \\
\hline Tellina spp. & + & + & + & + & + & + & + & + & + \\
\hline \multicolumn{10}{|l|}{ Gastropods } \\
\hline Bullia spp. & - & - & - & + & + & + & + & + & + \\
\hline Bursa spp. & - & - & - & + & + & + & + & + & + \\
\hline Cypraea spp. & - & - & - & + & + & + & + & + & + \\
\hline Cerithidea spp. & - & + & + & + & + & + & + & + & + \\
\hline Gastropod spats & + & + & + & + & + & + & + & + & + \\
\hline Littorina spp. & + & + & - & + & - & - & + & - & + \\
\hline Nassarius spp. & + & + & - & + & + & + & + & - & + \\
\hline Oliva spp. & - & + & + & + & + & + & + & + & + \\
\hline Patella spp. & + & - & - & + & + & - & - & - & + \\
\hline Surcula spp. & + & - & - & + & + & + & + & + & + \\
\hline Terebra spp. & - & - & - & + & + & + & + & + & + \\
\hline Thais spp. & + & - & - & + & + & + & + & + & + \\
\hline Tibia spp. & - & - & - & + & + & + & + & + & + \\
\hline Trochus spp. & + & - & - & + & + & + & + & + & + \\
\hline
\end{tabular}

90

Environment Conservation Journal 


\begin{tabular}{|c|c|c|c|c|c|c|c|c|c|}
\hline Turbo spp. & - & - & - & + & + & + & + & + & + \\
\hline Turitella spp. & + & + & + & + & + & + & + & + & + \\
\hline Umbonium spp. & + & + & - & + & + & + & + & + & + \\
\hline \multicolumn{10}{|l|}{ Scaphopods } \\
\hline Dentaliumoctangulata & + & - & + & + & - & - & + & + & + \\
\hline Dentalium spp. & + & + & + & + & + & + & + & + & + \\
\hline \multicolumn{10}{|l|}{ ARTHROPODA } \\
\hline \multicolumn{10}{|l|}{ Crustaceans } \\
\hline Amphipods & + & + & + & + & + & + & + & + & + \\
\hline Balanus spp. & + & + & - & + & + & - & + & + & + \\
\hline Copepods & + & + & + & + & + & + & + & + & + \\
\hline Emerita spp. & + & + & + & + & + & + & + & + & + \\
\hline Ocypode spp. & + & + & + & + & + & + & + & + & + \\
\hline Eupagurus spp. & - & + & - & + & + & + & + & + & + \\
\hline Lepasanatifera & + & - & - & - & - & - & - & - & + \\
\hline Mysids & + & + & + & + & + & + & + & + & + \\
\hline Uca spp. & + & + & + & + & + & + & + & + & + \\
\hline \multicolumn{10}{|l|}{ ANNELIDA } \\
\hline \multicolumn{10}{|l|}{ Polychaetes } \\
\hline Echiurus spp. & - & - & - & + & + & + & + & + & + \\
\hline Glycera spp. & + & + & + & + & + & + & + & + & + \\
\hline Nephthys spp. & - & - & + & + & + & + & + & + & + \\
\hline Nereis spp. & + & + & + & + & + & + & + & + & + \\
\hline Polychaete larvae & + & + & + & + & + & + & + & + & + \\
\hline Sabellaria spp. & - & + & + & + & + & - & + & + & + \\
\hline Nematodes & + & + & + & + & + & + & + & + & + \\
\hline \multicolumn{10}{|l|}{ ECHINODERMATA } \\
\hline Astropectenindica & - & - & - & + & + & + & + & + & + \\
\hline Clypeasteroids & + & + & + & + & - & - & + & + & + \\
\hline Ophiocoma spp. & - & - & - & + & + & + & + & + & + \\
\hline \multicolumn{10}{|l|}{ MISCELLANEOUS } \\
\hline Egg cases & + & + & + & + & + & + & + & + & + \\
\hline Fish larvae & - & - & - & + & + & + & + & + & + \\
\hline Sand tubes & + & + & + & + & + & + & + & + & + \\
\hline
\end{tabular}

In the present investigation, four major phyla were phylum, 19 classes, 52 orders and 102 families recorded, belonging to Mollusca, Arthropods, were documented intertidal benthic macrofauna of Annelida, Echinodermata and other miscellaneous a brackish water coastal lagoon Chilika lake on east were found at all nine stations of three selected coast of India by Debasish mahapatro et al. (2015) beaches. A total 135 no. of species belonging to 8 An intertidal environment provides the best study 


\section{Daggula et al.}

area to observe the seasonal changes of physicochemical process in relation to its inhabitants since a maximum of fluctuation is met in an estuaries and coastal ecosystem. important studies have been carried out on the macrobenthic ecology of various estuaries worldwide studied by Alogi (1990), Carvalho et al. (2001), Herman et al. (2001), Ysebaert et al. (2002), Bosire (2004), in India studied by Harkantra (1975), Ansari et al., 2004, Khan et al., 2004. A total of 60 different invertebrate macrofaunal species were identified from the intertidal regions of the Kathiawar Peninsula, Gujarath by Poonam Bhadja et al. (2014). The impact of environmental deterioration on the intertidal fauna has been studied by Datta et al. (2010), Chakraborty (2008), Jaiswar (2005) and Venkataraman (2005) in intertidal beaches of Mumbai coast.

\section{Seasonal variations in species distribution}

In present investigation intertidal organisms population varied between season to season and relatively high number of intertidal fauna recorded during the post-monsoon followed by pre-monsoon and monsoon season. High abundance of species observed in post and pre-monsoon may be high percentage of organisms also responsible for higher Margalef richness index throughout the study period at Panambur and Bengre beaches. Shannon's diversity index also indicated highly diverse community in respective beaches Pielou's evenness and Shannon's diversity indices revealed high evenness of the distribution except in the months of heavy monsoon (June and July) and the present investigation highest intertidal Abundance, distribution and diversity was recorded during post and pre-monsoon in Panambur and Bengre beaches the reason could be due to abounded fine sand and very fine sand substrate which shows the strongest correlation in post and pre-monsoon season with intertidal organisms according to Chakraborty et al. (2008) seasonal variations in the environmental factors and biological properties of organisms (breeding, gonadal maturity etc.) influence the occurrence of organisms in the intertidal region.

Table 2. Showing Someshwara beach sediment faunal Correlation (S1, S2 \& S3)

\begin{tabular}{|l|l|l|l|l|l|l|l|l|}
\hline \multicolumn{7}{|c|}{ Someshwara beach sediment faunal Correlation (S1, S2 \& S3) } \\
\hline Parameters & Granules & $\begin{array}{l}\text { Very } \\
\text { coarse } \\
\text { sand }\end{array}$ & $\begin{array}{l}\text { Coarse } \\
\text { sand }\end{array}$ & $\begin{array}{l}\text { Medium } \\
\text { sand }\end{array}$ & $\begin{array}{l}\text { Fine } \\
\text { sand }\end{array}$ & $\begin{array}{l}\text { Very } \\
\text { fine } \\
\text { sand }\end{array}$ & $\begin{array}{l}\text { Silt } \\
\text { clay }\end{array}$ & $\begin{array}{l}\text { Faunal } \\
\text { abundance }\end{array}$ \\
\hline Granules & 1.000 & & & & & & & \\
\hline Very coarse sand & 0.996 & 1.000 & & & & & & \\
\hline Coarse sand & 0.969 & 0.943 & 1.000 & & & & & \\
\hline Medium sand & -0.958 & -0.928 & $-.999^{*}$ & 1.000 & & & & \\
\hline Fine sand & -0.990 & $-.999^{*}$ & -0.926 & 0.909 & 1.000 & & & \\
\hline Very fine sand & $-1.000^{*}$ & $-.998^{*}$ & -0.963 & 0.951 & 0.993 & 1.000 & & \\
\hline Silt and clay & -0.262 & -0.348 & -0.016 & -0.027 & 0.393 & 0.285 & 1.000 & \\
\hline Faunal abundance & 0.990 & 0.974 & 0.994 & -0.988 & -0.962 & -0.987 & -0.126 & 1.000 \\
\hline
\end{tabular}

Table 3. Showing Panambur beach sediment faunal Correlation (P1, P2 \& P3)

\begin{tabular}{|l|l|l|l|l|l|l|l|l|}
\hline Panambur Correlation (P1, P2 \& P3) \\
\hline Parameters & Granules & $\begin{array}{l}\text { Very } \\
\text { coarse } \\
\text { sand }\end{array}$ & $\begin{array}{l}\text { Coarse } \\
\text { sand }\end{array}$ & $\begin{array}{l}\text { Medium } \\
\text { sand }\end{array}$ & $\begin{array}{l}\text { Fine } \\
\text { sand }\end{array}$ & $\begin{array}{l}\text { Very } \\
\text { fine sand }\end{array}$ & $\begin{array}{l}\text { Silt } \\
\text { and } \\
\text { clay }\end{array}$ & $\begin{array}{l}\text { Faunal } \\
\text { abundance }\end{array}$ \\
\hline Granules & 1.000 & & & & & & & \\
\hline Very coarse sand & 0.231 & 1.000 & & & & & & \\
\hline Coarse sand & -0.972 & -0.455 & 1.000 & & & & & \\
\hline Medium sand & $-1.000^{*}$ & -0.256 & 0.977 & 1.000 & & & & \\
\hline Fine sand & 0.936 & 0.559 & -0.993 & -0.945 & 1.000 & & & \\
\hline Very fine sand & -0.191 & $-.999^{*}$ & 0.418 & 0.216 & -0.524 & 1.000 & & \\
\hline Silt and clay & 0.983 & 0.051 & -0.913 & -0.979 & 0.857 & -0.010 & 1.000 & \\
\hline Faunal abundance & -0.738 & -0.827 & 0.877 & 0.755 & -0.928 & 0.803 & - & 1.000 \\
\hline
\end{tabular}


Relationship between grain size distribution and intertidal faunal abundance

Table 4. Showing Bengre beach sediment faunal Correlation (B1,B2 and B3)

\begin{tabular}{|c|c|c|c|c|c|c|c|c|}
\hline \multicolumn{9}{|c|}{ Bengre Correlations (B1,B2 and B3) } \\
\hline Parameters & Granules & $\begin{array}{c}\text { Very } \\
\text { coarse } \\
\text { sand } \\
\end{array}$ & $\begin{array}{c}\text { Coarse } \\
\text { sand }\end{array}$ & $\begin{array}{c}\text { Medium } \\
\text { sand }\end{array}$ & $\begin{array}{l}\text { Fine } \\
\text { sand }\end{array}$ & $\begin{array}{l}\text { Very } \\
\text { fine } \\
\text { sand } \\
\end{array}$ & $\begin{array}{l}\text { Silt } \\
\text { and } \\
\text { clay }\end{array}$ & $\begin{array}{c}\text { Faunal } \\
\text { abundance }\end{array}$ \\
\hline Granules & 1.000 & & & & & & & \\
\hline $\begin{array}{ll}\text { Very coarse } \\
\text { sand }\end{array}$ & -0.627 & 1.000 & & & & & & \\
\hline Coarse sand & -0.426 & 0.972 & 1.000 & & & & & \\
\hline Medium sand & 0.074 & 0.730 & 0.871 & 1.000 & & & & \\
\hline Fine sand & 0.261 & -0.915 & -0.984 & -0.944 & 1.000 & & & \\
\hline Very fine sand & 0.387 & -0.961 & $-.999^{*}$ & -0.891 & 0.991 & 1.000 & & \\
\hline Silt and clay & -0.721 & 0.992 & 0.934 & 0.638 & -0.857 & -0.918 & 1.000 & \\
\hline $\begin{array}{l}\text { Faunal } \\
\text { abundance }\end{array}$ & 0.892 & -0.207 & 0.029 & 0.517 & -0.204 & -0.072 & -0.329 & 1.000 \\
\hline
\end{tabular}

Table 4. Correlation coefficient (significant at $99 \%$ and $95 \%$ ) between Sediment fractions and intertidal organisms of the selected beaches of Mangaluru.

\begin{tabular}{|l|l|l|l|l|l|l|l|l|}
\hline \multicolumn{7}{|c|}{ Sediment fraction Correlation with intertidal faunal Abundance } \\
\hline Parameters & Granules & $\begin{array}{l}\text { very } \\
\text { coarse } \\
\text { sand }\end{array}$ & $\begin{array}{l}\text { coarse } \\
\text { sand }\end{array}$ & $\begin{array}{l}\text { Medium } \\
\text { sand }\end{array}$ & $\begin{array}{l}\text { fine } \\
\text { sand }\end{array}$ & $\begin{array}{l}\text { very } \\
\text { fine } \\
\text { sand }\end{array}$ & $\begin{array}{l}\text { silt } \\
\text { and } \\
\text { clay }\end{array}$ & $\begin{array}{l}\text { Faunal } \\
\text { abundance }\end{array}$ \\
\hline Granules & 1.000 & & & & & & & \\
\hline very coarse sand & $.970^{* *}$ & 1.000 & & & & & & \\
\hline coarse sand & $.823^{* *}$ & $.916^{* *}$ & 1.000 & & & & & \\
\hline Medium sand & -0.452 & -0.468 & -0.225 & 1.000 & & & & \\
\hline fine sand & $-.745^{*}$ & $-.825^{* *}$ & $-.961^{* *}$ & -0.045 & 1.000 & & & \\
\hline very fine sand & $-.906^{* *}$ & $-.939^{* *}$ & $-.936^{* *}$ & 0.200 & $.911^{* *}$ & 1.000 & & \\
\hline silt and clay & -0.518 & -0.607 & $-.735^{*}$ & -0.090 & $.760^{*}$ & $.771^{*}$ & 1.000 & \\
\hline $\begin{array}{l}\text { Faunal } \\
\text { abundance }\end{array}$ & $-.916^{* *}$ & $-.858^{* *}$ & $-.721^{*}$ & 0.278 & $.686^{*}$ & $.885^{* *}$ & 0.518 & 1.000 \\
\hline
\end{tabular}

\section{Simple Correlation}

Simple Correlation (Pearson's) was carried out for different physico-chemical parameters of water and sediment fractions to understand their interrelationships, which finally governs the productivity of the intertidal ecosystem. There was a significant positive correlation between air, water and sediment temperature at all three beaches and the statistical relationship indicated that the strong relationship between intertidal organisms and fine sand, whereas the organisms abundance negatively correlating with granules, very coarse and coarse sand.

\section{Conclusion}

Intertidal fauna abundance was observed with relation to the sediment fraction and physicochemical parameters in Someshwara beach,
Panambur beach and Bengre beach. Comparatively the percentage of fine sand was found to be more in Panambur and equally medium sand and coarse sand percentage was found to be dominated at Bengre beach where as Someshwara beach abounded with coarse sand percentage which is negatively correlating with intertidal fauna. In all the three beaches four phyla of invertebrates were recorded in which phylum Mollusca was dominated. Total bivalves (14genera), Gastropods (16 genera), Scaphopods (2 genera), Crustaceans (6 genera), Polychaetes (7 genera), Nematodes, Echinodermata (3 genera) were recorded in the present study. The statistical relationship indicated that the strong relationship between intertidal organisms and fine sand whereas the organisms abundance negatively correlating with granules, very coarse sand and coarse sand. All the nine 


\section{Daggula et al.}

stations were showing significant difference with seasonality in physico-chemical parameters, sediment fractions and intertidal faunal composition Beach profile, topography and grain size distribution are the most important factors in abundance and distribution of intertidal organisms. The study concludes that though these beaches are moderately disturbed due to anthropogenic activities, they still support a rich intertidal biodiversity which needs immediate attention for protection and conservation. The present baseline information is useful for the further ecological monitoring and assessment along the coastal beaches.

\section{References}

Alogi. 1990. Interdecadal variability and climate change in the Eastern Tropical Pacific: A review. Progress in Oceanography. 12:1-34.

Amrutha, N. S., 2010. Abundance and Distribution of Horn shell (Cerithidea cingulate)(GMELIN) in the brackish waters of Netravathi estuary, Mangalore. M.F.Sc. Thesis, Kar. Vet. Anim. Fish. Sci. Uni., Bidar.

Ansari, Z.A., Sreepada, R. A., Kanti, A., Gracias, E.S., 2004. Macrobenthic assemblage in (the soil sediment of Murmugoa harbour, Goa Central West Coast of India). Indian J. Mar. Sci.,23: 225-231.

Bosire, B.B., 2004. Observations on the hydrology of Hooghly estuary. Indian J. Fish.,3(1): 101-118.

Carvalho, A., Mees, J. and Hamerlynck, O., 2001. The hyperbenthic Amphipoda and Isopoda of the Voor Delta and Westerschelde estuary. Castel, J.; Heip,-C.,: 187-200.

Chakraborty, S. K., 2011. A multi-method approach for the study of lanthanum speciation in coastal land estuarine sediments. Journal of Geochemical Exploration, 110:225231.

Chakraborty, S.K., Jaiswar, A.K. and Ziauddin, G., 2008. A comparative study on intertidal faunal biodiversity of selected beaches of Mumbai coast. Journal of Environmental Biology, 31(6): 981-986.

Chethan, N., 2012. Temporal variability of phytoplankton assemblage in the coastal waters of Mangalore. Ph. D. thesis, Karnataka Veterinary, Animal and Fisheries Sciences University, Bidar.

D'souza, R.K., 2001. Distribution of eggs and larvae of finfish and shellfish in relation to selected hydrographical parameters and phytoplankton in the coastal waters off Dakshina Kannada. M.F.Sc., thesis, University of Agricultural Sciences, Bangalore, India
Damotharan, P., Perumal, N. V., Arumugam, M., Vijayalakshmi, S., and Balasubramanian, T. 2010. Seasonal variation of physicochemical characteristics in Point Calimere coastal waters (south east coast of India). Middle-East Journal of Scientific Research, 6 (4), 333339.

Datta, S. N., Chakraborty, S., K., Jaiswar, A.K., Ziauddin, G., 2010. A comparative study on intertidal faunal biodiversity of selected beaches of Mumbai coast. Journal of Environmental Biology, 31(6): 981-986.

Debasish Mahapatro, Panigrahy, R.. Panda, C.,S. and Mishra, R.K., 2015. Checklist of intertidal benthic macrofauna of a brackish water coastal lagoon on east coast of India. The Chilika lake International Journal of Marine Science, 5 (33):1-13.

Engston., 1974. Environmental impacts of sand and gravel extraction on river systems. In The Brisbane river, (Ed. Erskine, W.D.):295-303.

Ganapathi Naik., 2012. Influence of environmental factors on the oyster beds of Mulky estuary. Ph.D. Thesis, Kar. Vet. Anim. Fish. Sci. Uni., Bidar.

Gopalakrishnan, T.C. and Nair, K.K.C., 1998. Subtidal benthic macrofauna of the Mangalore coast, west coast of India. Ind. J Mar. Sci., 27:351-355.

Govindasamy, C., Kannan, L. and Jayapaul, A., 2000. Seasonal variation in physicochemical properties and primary production in the coastal water biotopes of Coromandel Coast. Ind. J. Env. Bio.,21(1):17.

Harkantra S. N., Rodrigues C. L., and Parulekar A. H., 1982. Macrobenthos of the shelf off northeastern Bay of Bengal. Indian Journal of Marine Sciences, 11: 115-121.

Herman, J.E., Copeland, B.J. and Harrison, W.G., 2001. Source and fates of nutrients of the Palmico river estuary, In: Cronin, L.E. (Ed.) Chemistry biology and the estuarine system. 1: 287-302. Academics press, New York, U.S.A.

Hopkison, Grant, G.M. and Gross, E., 1999. The Chemistry and Fertility of Sea Water, Cambridge University Press, London: 240.

Jaiswar, A. K. and Kulkarni B. G., 2005. Conservation of Molluscan biodiversity from intertidal area of Mumbai coast. J. Natcon, 17(1): 93-105.

Karl D. M., 2000. Aquatic ecology: phosphorus, the staff of life. Nature, 406: 31-33.

Katti, R. J., Moorthy, K.S.V., Kumar, B. M., D'souza, R. and Santhanagouda, A.H., 2002. Planktonic crustaceans in relation to hydrography in the Arabian sea off Chitrapur receiving industrial effluents. 
Katti, R.J., Kumar, B.M., Moorthy, K.S.V. and De'souza, R., 2001. Hydrography and net phytoplankton in the Arabian Sea off Chitrapur receiving industrial effluents -pre and post assessment. Poll. Res., 20(3):373-382.

Khan, Ajmal, J.R.L. RAE, J.E. and ZANIN, P.E., 2004. Metal speciation $(\mathrm{Cu}, \mathrm{Zn}, \mathrm{Pb})$ and organic matter in an oxic salt marsh, Severn estuary, south west Britain. Mar. pollut. Bull, 21 (12): 574-580.

Komar, P.D., 1976. Beach Processes and Sedimentation, New Jersey, Prentice-Hall, : 1-429.

Lingadhal, C., 1991. Ecological monitoring of the inshore waters off Mangalore. M. F. Sc. Thesis, Univ. Agril. Sci., Bangalore: 126.

Madhavi, K., 2014. Nutrient and phytoplankton dynamics along the riverine, estuarine and coastal transects off Mangalore, Southwest coast of India. Ph.D. thesis, Karnataka Veterinary, Animal and Fisheries Sciences University, Bidar.

Madukumari, 2007. Arabian Sea oceanography and fisheries off the West coast of India. Curr. Sci., 81: 355-361.

Manjappa, H., Gowda, G., Rajesh, K.M., and Mridula, K.M., 2003. Sediment characteristics of mangrove area of brackish water impoundments. Ind. J. Fish. 50(3): 349354.

Manjappa, K., 1999. Distribution of chlorophyll and phaeopigments in relation to hydrographical parameters in the Arabian sea off Mangalore. M.F.Sc. Thesis. Univ. Agric. Sci., Bangalore: 126.

Mohan, B., 1999. Distribution of macrobenthic organisms in relation to the selected sediment characteristics in the Arabian Sea off Chitrapur receiving industrial effluents. M.F.Sc., Thesis, University of Agricultural Sciences, Bangalore: 85.

Muruganantham, P., GOpalakrishnan, T., Chandrasekaran, R. and Jeyachandran, S., 2012. Seasonal Variations and Diversity of Planktonic Diatoms of Kodikkarai and Velanganni, Southeast Coast of India. Journal of Oceanography and Marine Environmental System. 2(1): $01-10$

Padmavati, G and Goswami, S.C., 1996. Zooplankton ecology in the Mandovi- Zuari estuarine system of Goa, west coast of India. Ind. J. Mar. Sci., 25: 268-273.

Parsons, T.R., Maitha, Y. and Lalli, C.M., 1989. A manual of chemical and biological methods for sea water analysis. Pergamon Press, New York:173

Poonam Bhadja, Paresh Poriya,.Kunda., 2014, Community Structure and Distribution Pattern of Intertidal Invertebrate Macrofauna at Some Anthropogenically
Influenced Coasts of Kathiawar Peninsula (India) Advances in Ecology,. 11:547-395.

Prabhu, H.V., 1992. Sedimentlogical and biological studies of sediments off Honnavar, North Kanara, west coast of India. Ph. D. Thesis, Mangalore University, Mangalagangothri: $1-223$.

Prashanth. 2010. Study on Distribution of top snail (Telescopiumtelescopium) in mangrove along the Netravathi estuary, Mangalore. M.F.Sc. Thesis, Kar. Vet. Anim. Fish. Sci. Uni., Bidar.

Rajashekar, K. S., 2010. Distribution of zooplankton with special reference to meroplankton in relation to selected hydrographic parameters in the coastal waters off Thannirbhavi, Dakshina Kannada. M. F. Sc. Thesis, Uni. Agril. Sci., Bangalore.

Rajeshwari, V., 2009. Macrobenthic community structure in relation to sediment characteristics in the coastal waters of Padubidri, Udupi district. M.F.Sc. Thesis, Kar. Vet. Anim. Fish. Sci. Uni., Bidar.

Ramachandra U., 1981. Studies on the macrobenthos of Mulki estuary, Dakshina Kannada., M.F.Sc. Thesis Univ. Agri. Sci., Bangalore: 219.

Ramalingam, M., Subramanian, A. and Abdul Hameed, M.H., 2001. Seasonal Variations of physico-chemical properties of the Great Vedaranyam Swamp, Point Calimere Wildlife Sanctuary, South-east coast of India. Afr. J. Env. Sci. Technol. 5(9):12-49.

Raveesha, K.P., 2007. Distribution of plankton in the Arabian Sea off Mangalore. Ph.D. Thesis, Kar. Vet. Anim. Fish. Sci. Uni., Bidar.

Reddy Gopala, K., 1982. Studies on the plankton of Mulki estuary in relation to hydrography. M.F.Sc. Thesis, Univ. Agril. Sci., Bangalore, India.

Sahu, G., Satpathy, K.K., Mohanty, A.K., Sarkar, S.K., 2012. Variations in community structure of phytoplankton in relation to physicochemical properties of coastal waters, south east coast of India. Indian J. Geo-Mar. Sci. 41(3):223-241.

Saritha, D., Sajikumar, S. and Machado, T., 1996. Sand and clay mining in the Vamanapuram river basin and its environmental impacts. Proceedings of the $8^{\text {th }}$ Kerala Science Congress, Kochi, 20.

Sampathkumar, P. and Kannan, L., 1998. Seasonal variations in physicochemical characteristics in the TranquebarNagapattinam region, Southeast coast of India. Poll. Res., 17(4): 397-402.

Santhanam, P. and Perumal, P., 2003. Diversity of zooplankton in Parangipettai coastal waters south east coast of India. $J$. Mar. Ass. Ind., 45(2):144-151. 


\section{Daggula et al.}

Selvaraj, P., and Rammohan, G.K., 2003. Studies on the physico-chemical characteristics and nutrients in the Uppanar estuary of Cuddalore, Southeast coast of India. Curr. Res. J. Bio. Sci., 1(3): 102-105.

Senthilkumar, S., Santhanam, P. and Perumal, P., 2002. Diversity of phytoplankton in Vellar estuary, southeast coast of India. In: The 5th Indian Fisheries Forum Proceedings. Jena SJK \& M Mohan Joseph (Eds.). Published by AFSIB, Mangalore and AeA, Bhubaneswar, India.

Seralathan, P., Meenaksid Kutty, N.R., Ashrafe, K.V. and Padmlal, D., 1993. Sediment and organic carbon distributions in the Cochin harbour area. Indian J. Mar Sci., 22: 252-255.

Shanthanagouda, A.H., 2001. Macrobenthos in relation to sediment characteristics in Nethravati-Gurupur estuary. M.F.Sc. Thesis, University of Agri, Sci., Bangalore, India

Shiva Kumar, K.S., 2005. Macrobenthos of Mulki -Pavanje Estuarine complex, Dakshina Kannada, M.F.Sc. Thesis, K.V.A.F.S.U., Bidar, Karnataka, India

Shruthi, 2015. Species diversity of diatoms in relation to hydrographical characteristics in the coastal waters off Dakshina Kannada and Udupi district. M.F.Sc. Thesis, Kar. Vet. Anim. Fish. Sci. Uni., Bidar.

Shruthi, M.S. and Rajashekhar, M., 2013. Ecological observations on the phytoplankton of Nethravati Gurupura estuary, south west coast of India. Mar. Biol. Ass. Ind., 55 (2): 41- 47.

Sridhar, R., Thangaradjou, T., Senthil Kumar, S. and Kannan, L., 2006. Water quality and phytoplankton characteristics in the Palk Bay, Southeast coast of India. J. Env. Biol.,27: 561-566.
Srinivasulu, M., Gouri Sahu, Mohanty, A. K., Samatara, M. K., Panigrahy, S. N., Selvanyagam, M., Satpathy, K. K., Prasad, M.V.R. and Panigrahy, R.C., 2007. Phytoplankton abundance and diversity in the coastal water of Kalpakkam, East Coast of India in relation to the environmental variables. Bioscan. 2:553-568.

Strickland, J.D.H. and Parsons, T.R., 1972. A practical hand book of sea water analysis. Bull. Fish. Res. Bd. Can., 167: 331

Sushanth, V.R. and Rajashekhar, M., 2012. Seasonal variation in diatoms in response to physico-chemical characteristics of coastal waters of Uttara Kannada district, West Coast of India. Int. J. Env. Sce., 2(3): 1543-1552.

Swetha, 2009. Meiofauna in relation to sediment characteristics in Mulki estuary, Dakshina Kannada. M.F.Sc., thesis. Kar. Vet. Ani. Fish. Sci. Univ., Bidar.

Tripathi, S.K., 2002. Distribution of phytoplankton in relation to hydrographic parameters of Nethravati-Gurupur estuary, Mangalore (Dakshina Kannada). M.F.Sc., thesis, University of Agricultural Sciences, Bangalore, India.

Vijaya Kumar, S.K., Rajesh, K.M., Mendon, M.R. and Hariharan, V., 2000. Seasonal distribution and behavior of nutrients with reference to tidal rhythm in the Mulki estuary, South West Coast of India. J. Mar. Biol. Ass. India. 42: 21-31.

Ysebaert, J.D., Jones, B. H., Dickey, T. D., Brink, K. H., Weller, R. A., Marra, J. and Codispoti, L.A., 2002. The Northeast Monsoon's impact on mixing, phytoplankton biomass and nutrient cycling in the Arabian Sea. $\boldsymbol{J}$. of Deep-Sea Res., 2(47): 1353-1385. 